\title{
Peningkatan ketahanan oksidasi karet alam melalui pengikatan antioksidan 4-aminodifenilamina secara kimia
}

\section{The improvement of natural rubber oxidation resistance through 4-aminodiphenylamine chemical bonding}

\author{
Hani Handayani ${ }^{1, *}$, Dadi R. Maspanger ${ }^{1}$, Cynthia L. Radiman² \\ ${ }^{1}$ Pusat Penelitian Karet, Jalan Salak No.1, Bogor 16151, Indonesia \\ ${ }^{2}$ Institut Teknologi Bandung, Jalan Ganesha No. 10, Bandung 40116, Indonesia \\ *Penulis korespondensi. Telp.: +62 251 8319817; Fax.: +62 2518324047 \\ E-mail: hani.ppkbogor@gmail.com
}

Diterima: 8 Agustus 2016 Direvisi: 15 September $2016 \quad$ Disetujui: 16 September 2016

\begin{abstract}
Natural rubber is very important in supporting the Indonesian economy from non-oil sector. However, natural rubber is not resistant to oxidation. Various attempts have been made to overcome the weaknesses; one of them is the addition of antioxidants as additives in the manufacture of rubber goods. However, it has the disadvantage of mechanical technique, including antioxidant blooming, resulting in failed products and decrease in antioxidants ability. The aim of this research is to improve the resistance of natural rubber from oxidation through the chemically-bound antioxidant into epoxidized latex. Fresh latex was deproteinized using 0.06 phr papain. Latex was epoxidized using formic acid and hydrogen peroxide at $70^{\circ} \mathrm{C}$ with stirring speed of 700 rpm for 3 hours. Then the 4-aminodiphenylamine (4-ADPA) antioxidant was added with three variations mole percent of 4-ADPA between 0.025 to $0.1 \mathrm{~mol} / 100$ grams of rubber, and four variations in temperature were applied (between $27-80^{\circ} \mathrm{C}$ ). The results showed that the optimum condition for the binding was at $27^{\circ} \mathrm{C}$ at a dose of antioxidants as much as 0.1 mol/100 grams of rubber. The analysis of FTIR spectra revealed that the binding of 4-ADPA into the epoxidized latex was as much as $1.93 \mathrm{phr}$. The rheometer curve analysis showed that the natural rubber bound 4-ADPA was more resistant to ageing based on the value of $R_{300^{\circ}}$
\end{abstract}

Keywords: latex, antioxidant, epoxidation, 4-ADPA, natural rubber oxidation.

\begin{abstract}
ABSTRAK
Karet alam berperan penting sebagai sumber devisa negara dari sektor nonmigas. Akan tetapi karet alam tidak tahan terhadap oksidasi. Berbagai upaya telah dilakukan untuk mengatasi hal tersebut, salah satunya dengan menambahkan antioksidan sebagai aditif pada pembuatan barang jadi karet. Akan tetapi cara ini rentan mengalami blooming sehingga menimbulkan cacat produk dan penurunan daya antioksidasi. Penelitian ini bertujuan untuk meningkatkan ketahanan oksidasi karet alam melalui pengikatan antioksidan secara kimia ke dalam lateks yang sudah diepoksidasi. Lateks kebun dideproteinisasi menggunakan enzim papain sebanyak 0,06 phr, setelah itu diepoksidasi menggunakan asam format dan hidrogen peroksida pada suhu $70^{\circ} \mathrm{C}$ dengan kecepatan pengadukan $700 \mathrm{rpm}$ selama $3 \mathrm{jam}$. Ke dalam lateks epoksi tersebut kemudian ditambahkan 4-ADPA pada tiga variasi dosis antara 0,025-0,1 mol/100 gram karet, dan empat variasi suhu antara $27-80^{\circ} \mathrm{C}$. Dari hasil penelitian diperoleh kondisi optimum untuk pengikatan adalah $27^{\circ} \mathrm{C}$ dengan dosis antioksidan sebanyak 0,1 mol/100 gram karet. Hasil spektrum FTIR menunjukkan telah terjadi pengikatan 4-ADPA ke dalam lateks yang telah terepoksidasi sebanyak 1,93 phr. Hasil analisis kurva reometer menunjukkan karet yang mengikat 4-ADPA secara kimia lebih tahan terhadap pengusangan berdasarkan nilai $\mathrm{R}_{300}$.
\end{abstract}

Kata kunci: lateks, antioksidan, epoksidasi, 4-ADPA, oksidasi karet alam. 


\section{PENDAHULUAN}

Karet alam merupakan salah satu komoditas perkebunan yang sangat penting dalam menunjang perekonomian Indonesia karena berperan sebagai sumber devisa negara dari sektor nonmigas. Data tahun 2014 menunjukkan luas areal tanaman karet di Indonesia adalah seluas 3,61 juta hek$\operatorname{tar}$ (ha) dan menempati areal perkebunan terluas ketiga setelah kelapa sawit dan kelapa (Deptan, 2016). Indonesia menjadi negara kedua produsen karet terbesar di dunia setelah Thailand, yang produksinya tahun 2014 mencapai 3,15 juta ton. Sebagai negara produsen karet alam terbesar kedua di dunia, Indonesia memiliki potensi yang besar menjadi pengendali pasar karet alam dalam negeri. Langkah-langkah yang dapat ditempuh di antaranya melalui pengembangan produk karet untuk industri barang jadi karet alam serta diversifikasi produk karet alam. Salah satu bentuk diversifikasi produk karet alam adalah dengan modifikasi struktur molekul karet alam baik secara fisika maupun kimia sehingga diperoleh material baru yang memiliki karakteristik unik untuk penggunaan yang lebih luas dalam bidang tertentu.

Karet alam mempunyai beberapa kelemahan, antara lain sifatnya tidak konsisten, tidak tahan terhadap cuaca, panas, pelarut hidrokarbon, dan ozon, sehingga tidak dapat digunakan sebagai bahan baku barang jadi karet, terutama untuk barang yang tahan minyak, panas, dan oksidasi. Hal ini disebabkan oleh struktur cis-1,4-poliisoprena dari karet alam mempunyai ketidakjenuhan yang tinggi dengan kandungan ikatan tidak jenuh pada rantai molekulnya sekitar 15.000-20.000. Disamping itu, karet alam bersifat nonpolar sehingga tidak tahan terhadap minyak (Faturrahman et al., 2011; Phinyocheep et al., 2005). Berbagai kelemahan tersebut telah membatasi bidang penggunaan karet alam, terutama untuk pembuatan barang jadi karet teknik yang harus tahan terhadap lingkungan ekstrim. Hal ini menyebabkan penggunaan karet alam banyak digantikan oleh karet sintetik.

Berbagai upaya telah dilakukan untuk mengatasi kelemahan karet alam baik secara fisika melalui pencampuran (blending) dengan karet sintetik atau plastik maupun secara kimia melalui perubahan struktur molekulnya. Salah satunya adalah dengan meningkatkan ketahanan karet alam terhadap oksidasi melalui penambahan bahan antioksidan sebagai aditif pada proses pembuatan barang jadi karet. Antioksidan biasanya ditambahkan ke dalam karet baik secara mekanis (di dalam open mill pada saat komponding yaitu proses pencampuran karet dengan bahan-bahan aditif lainnya) maupun secara kimia melalui reaksi modifikasi.

Umumnya penambahan antioksidan dilakukan pada saat komponding karena prosesnya relatif lebih mudah dan murah. Akan tetapi cara mekanis ini memiliki kelemahan diantaranya bahan antioksidan yang ditambahkan rentan mengalami blooming (migrasi ke permukaan karet) sehingga menimbulkan cacat produk dan penurunan daya antioksidasi. Salah satu cara untuk mengatasi hal tersebut adalah dengan mengikatkan bahan antioksidan secara kimia ke dalam lateks yang sudah diepoksidasi.

Reaksi epoksidasi adalah reaksi oksidasi ikatan rangkap dalam karet alam oleh oksigen aktif membentuk senyawa epoksida atau cincin oksiran. Cincin oksiran adalah suatu gugus yang reaktif sehingga mudah mengalami reaksi pembukaan cincin (Phinyocheep, 2014). Dengan demikian, pengikatan antioksidan ke dalam rantai molekul karet alam memungkinkan untuk dilakukan melalui pembentukan gugus oksiran.

Klinpituksa et al. (2011) berhasil melakukan bounding (pengikatan) senyawa amina aromatik 4-ADPA (4-aminodifenilamina) sebanyak 1-4 phr ke dalam karet epoksi melalui gugus oksiran. Hasilnya diperoleh karet alam yang lebih tahan oksidasi. Reaksi pengikatan bahan antioksidan tersebut ke dalam karet dapat dilihat pada Gambar 1.

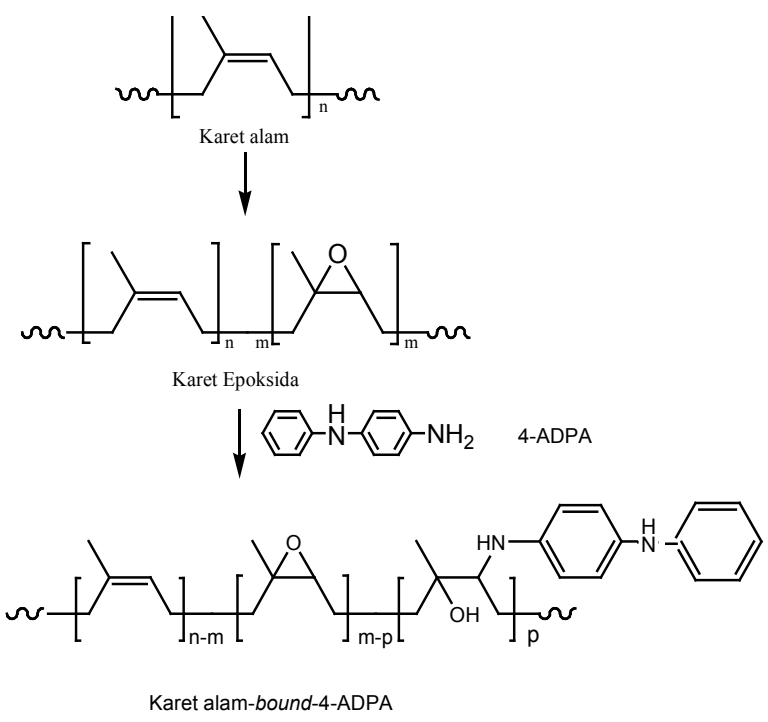

Gambar 1. Reaksi pengikatan 4-ADPA ke dalam karet alam melalui gugus epoksi (Klinpituksa et al., 2011). 
Dengan terikatnya antioksidan secara kimia diharapkan ikatan antara antioksidan dengan karet alam lebih kuat sehingga tidak terjadi blooming dan akhirnya karet menjadi lebih tahan terhadap oksidasi dibandingkan dengan karet yang ditambahkan antioksidan secara mekanis.

\section{BAHAN DAN METODE Bahan Penelitian}

Bahan yang digunakan dalam penelitian ini meliputi lateks kebun yang diperoleh dari Kebun Percobaan Ciomas Bogor, antioksidan 4-aminodifenilamina (4-ADPA) dari Sigma Aldrich, surfaktan emulgen dari KAO, pelarut dengan grade p.a. (kloroform, aseton, dan metanol) dari Merck, enzim papain, asam format, hidrogen peroksida, amonia, natrium tiosulfat, bahan-bahan untuk penentuan kadar nitrogen, dan bahan-bahan komponding (sulfur, asam stearat, seng oksida, carbon black, dan bahan pencepat) yang diperoleh dari pemasok lokal.

\section{Peralatan Penelitian}

Peralatan penelitian meliputi reaktor gelas leher tiga yang dilengkapi dengan labu tetes untuk menempatkan hidrogen peroksida, termometer gelas, dan pelat pemanas (hot plate) dengan pengaduk magnet (magnetic stirrer) dari Fisher Scientific. Peralatan untuk pemurnian hasil berupa alat ekstraksi sokhlet yang dilengkapi dengan pemanas listrik dari Barnstead Electrothermal. Gilingan kreper untuk membuat karet krep dan untuk pengeringannya digunakan oven. Peralatan untuk karakterisasi spektrum FTIR berupa spektrofotometer FTIR Thermo Scientific Nicolet iS5. Peralatan untuk preparasi kompon berupa gilingan terbuka (open mill), serta reometer MDR 2000 .

\section{Metode Penelitian \\ Pembuatan lateks DPNR}

Lateks kebun ditentukan KKK (Kadar Karet Kering) setelah itu ke dalamnya ditambahkan surfaktan emulgen sebanyak $3 \mathrm{phr}$ dan enzim papain sebanyak $0,06 \mathrm{phr}$. Selanjutnya lateks diencerkan hingga KKK 20\% kemudian diinkubasi selama 24 jam. Setelah itu lateks DPNR diuji kadar nitrogennya dan dibandingkan dengan lateks kebun untuk memastikan bahwa protein dalam lateks kebun telah terhidrolisis. Kadar nitrogen ditentukan menggunakan metode uji SNI 06-1903-1990.

\section{Pembuatan lateks epoksi}

Reaksi epoksidasi diawali dengan menentukan kondisi optimum melalui variasi suhu, waktu reaksi, dan kecepatan pengadukan. Variasi suhu yang digunakan adalah 60,70 , dan $80^{\circ} \mathrm{C}$ selama 1 , 2, 3, dan 4 jam dengan kecepatan pengadukan 125 , 350, dan $700 \mathrm{rpm}$. Setelah diperoleh kondisi optimum selanjutnya sebanyak $200 \mathrm{ml}$ lateks DPNR dengan KKK $20 \%$ ditempatkan di dalam reaktor berkapasitas $500 \mathrm{~mL}$ yang dilengkapi dengan pengaduk magnetis. Selanjutnya ke dalam lateks ditambahkan asam format dengan dosis $0,3 \mathrm{~mol} /$ mol isoprena unit. Campuran direaksikan hingga mencapai suhu optimum. Setelah mencapai suhu optimum ke dalam reaktor ditambahkan hidrogen peroksida secara perlahan tetes demi tetes sebanyak $0,75 \mathrm{~mol} / \mathrm{mol}$ unit isoprena. Titik nol penghitungan waktu dimulai ketika semua peroksida selesai ditambahkan. Selanjutnya reaksi dijalankan selama 1-4 jam pada kecepatan pengadukan optimum hingga terbentuk lateks epoksi.

Persen lateks terepoksidasi dapat dihitung secara kuantitatif menggunakan data dari spektrum FTIR dengan cara menghitung absorbansi dari pita karakteristik untuk cincin epoksida pada bilangan gelombang $870 \mathrm{~cm}^{-1}$, cincin terbuka pada bilangan gelombang $3460 \mathrm{~cm}^{-1}$, gugus $-\mathrm{CH}_{3}$ dari karet alam pada bilangan gelombang $1375 \mathrm{~cm}^{-1}$ serta olefin yang tidak termodifikasi pada bilangan gelombang $835 \mathrm{~cm}^{-1}$. Rumus untuk menghitung persen karet yang terepoksidasi (E) dan persen cincin terbuka (R) menurut Chakraborty et al. (2010) adalah sebagai berikut:

$$
E=\frac{100 \cdot K_{1} \cdot A_{870 \text { corr. }}}{A_{835}+K_{1} \cdot A_{870 \text { corr. }}+K_{2} \cdot A_{3460 \text { corr. }}}
$$

dan

$\mathrm{R}=100-\mathrm{E}-\left[\frac{\mathrm{A}_{835}}{\mathrm{~K}_{1}} \times \frac{\mathrm{E}}{\mathrm{A}_{870 \text { corr. }}}\right]$

dengan:

$\mathrm{E} \quad=$ persen mol lateks terepoksidasi

$\mathrm{R}=$ persen mol cincin oksiran yang terbuka

$\mathrm{A}_{870 \text { corr. }}=\mathrm{A}_{870}-0,14 \times \mathrm{A}_{835}$

$A_{3460 \text { corr. }}=A_{3460}-0,019 \times A_{1375}$

\section{Pengikatan antioksidan melalui gugus epoksi}

Lateks epoksi yang dihasilkan dinetralkan dengan amonia dan natrium tiosulfat. Selanjutnya ke dalam lateks tersebut ditambahkan antioksidan yang telah didispersikan ke dalam campuran amonia, asam oleat, dan air dengan komposisi dispersi 
$50 \%$. Antioksidan dengan tiga variasi dosis yaitu 0,$025 ; 0,05$; dan $0,1 \mathrm{~mol} / 100$ gram karet ditambahkan secara perlahan tetes demi tetes. Reaksi dijalankan pada empat variasi suhu yaitu 27, 60, 70 , dan $80^{\circ} \mathrm{C}$.

Setelah reaksi selesai karet digumpalkan dengan metanol kemudian digiling dengan gilingan kreper dan dikeringkan pada suhu $50^{\circ} \mathrm{C}$. Selanjutnya karet tersebut dimurnikan dengan aseton secara sokletasi selama 8 jam untuk menghilangkan antioksidan yang tidak terikat. Lateks tersebut kemudian dikarakterisasi menggunakan spektrofotometer FTIR untuk memastikan bahwa antioksidan telah terikat secara kimia ke dalam lateks epoksi.

Karet yang telah terikat dengan antioksidan pada berbagai dosis dikarakterisasi dengan spektrofotometer FTIR. Jumlah antioksidan yang terikat dihitung dengan cara membandingkan absorbansi pada bilangan gelombang $1596 \mathrm{~cm}^{-1}$ dan $1375 \mathrm{~cm}^{-1}$ yang karakteristik untuk gugus -NH dari 4-ADPA dan gugus $-\mathrm{CH}_{3}$ dari karet alam. Jumlah 4-ADPA yang terikat pada karet alam ditentukan berdasarkan kurva standar yang diperoleh dari pencampuran secara fisika karet alam dengan antioksidan pada dosis 1, 2, 3, 4, dan 5 phr (Barra et al., 1999).

\section{Pembuatan dan karakterisasi vulkanisat}

Karet yang berhasil diperoleh selanjutnya digiling dengan bahan-bahan lain di dalam open mill sesuai dengan resep kompon ASTM 2A (Tabel 1). Kompon tersebut kemudian divulkanisasi hingga membentuk vulkanisat di dalam mesin press vulkanisasi pada suhu $150^{\circ} \mathrm{C}$ selama waktu tertentu sesuai dengan hasil reometernya yang diukur dengan alat reometer MDR 2000.
Berdasarkan kurva reometer dapat diketahui ketahanan usang dari suatu kompon dengan menghitung ketahanan reversinya sesuai dengan rumus Khang and Ariff (2011) berikut ini:

$\mathrm{R}_{300}(\%)=\frac{\mathrm{S}_{\max }-\mathrm{S}_{300 \mathrm{~s}}}{\mathrm{~S}_{\max }} \times 100 \%$

$\mathrm{R}_{300}$ adalah persen reversi dari kompon karet pada 300 detik setelah $\mathrm{S}_{\max }, \mathrm{S}_{\text {max }}$ adalah maximum torque, dan $\mathrm{S}_{300 \mathrm{~s}}$ adalah nilai torque pada 300 detik setelah maximum torque $\left(\mathrm{S}_{\max }\right)$.

\section{HASIL DAN PEMBAHASAN Pembuatan Lateks DPNR}

Reaksi epoksidasi dipengaruhi oleh kadar protein yang terkandung di dalam lateks. Semakin banyak kandungan proteinnya, reaksi epoksidasi semakin sulit berlangsung. Hal ini disebabkan karena asam performat yang terbentuk secara in situ (antara asam format dan hidrogen peroksida) sulit bereaksi dengan gugus isoprena molekul karet karena terhalang oleh protein yang ada di dalam lateks. Dalam penelitian ini digunakan lateks DPNR yang kandungan proteinnya sengaja dikurangi secara enzimatis dengan menggunakan enzim papain sehingga diharapkan reaksi epoksidasi dapat berlangsung lebih cepat dan optimal (Faturrahman et al., 2011). Enzim papain dipilih karena harganya relatif murah, prosesnya mudah, dan hasilnya cukup baik.

Hasil penentuan kadar nitrogen dari lateks DPNR sebesar 0,05\%. Nilai ini jauh lebih kecil dibandingkan lateks kebun yaitu sebesar $0,25 \%$. Dengan demikian setelah dilakukan deproteinisasi terjadi penurunan kadar nitrogen sebesar $80 \%$. Hal ini menunjukkan bahwa proses deproteinisasi

Tabel 1. Susunan resep kompon vulkanisat ASTM 2A.

\begin{tabular}{lcccc}
\hline \multirow{2}{*}{ Komposisi } & \multicolumn{4}{c}{ Jumlah (phr) } \\
\cline { 2 - 5 } & Kompon A & Kompon B & Kompon C & Kompon D \\
\hline Karet alam & 100 & 100 & - & - \\
ENR-30 & - & - & 100 & - \\
NR-bound-4-ADPA & - & - & - & 100 \\
Seng oksida & 5 & 5 & 5 & 5 \\
Asam stearat & 2 & 2 & 2 & 2 \\
Carbon black 330 & 35 & 35 & 35 & 35 \\
Sulfur & 2,25 & 2,25 & 2,25 & 2,25 \\
TBBS & 0,7 & 0,7 & 0,7 & 0,7 \\
4-ADPA & - & 1 & 1 & - \\
\hline
\end{tabular}


lateks kebun dengan enzim papain yang dilakukan pada penelitian ini telah berhasil menghidrolisis protein lateks kebun sekitar $80 \%$ dan menghasilkan lateks DPNR dengan kadar nitrogen yang rendah.

\section{Pembuatan Lateks Epoksi}

Reaksi epoksidasi dalam penelitian ini menggunakan pereaksi hidrogen peroksida dan asam format untuk menghasilkan asam performat. Asam format dipilih karena tidak memerlukan katalis (Phinyocheep \& Boonjairaak, 2006). Optimasi telah dilakukan untuk menentukan kondisi optimum dengan melakukan epoksidasi pada variasi suhu, waktu, dan kecepatan pengadukan. Jumlah hidro-

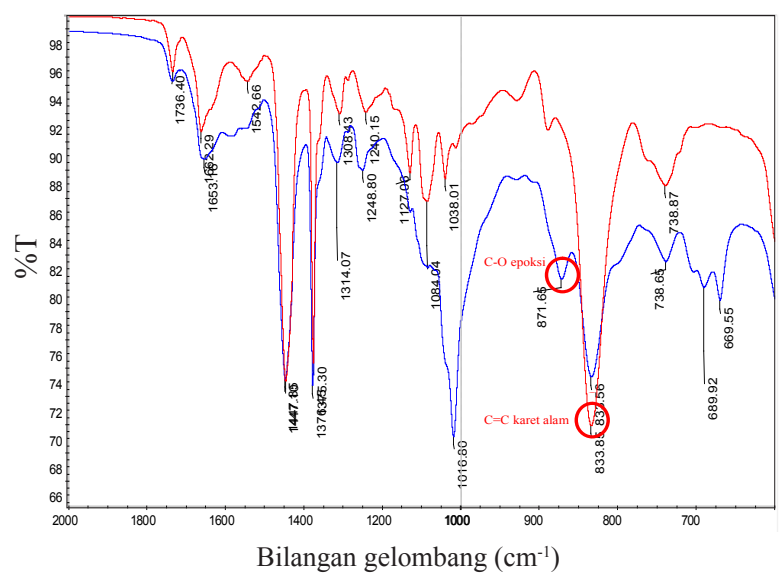

Gambar 2. Perbandingan spektrum FTIR karet alam (merah) dengan karet ENR-25 (biru). gen peroksida dan asam format yang direaksikan dibuat tetap pada dosis optimal sesuai dengan hasil penelitian pendahuluan yaitu asam format sebanyak $0,3 \mathrm{~mol} / \mathrm{mol}$ unit isoprena dan hidrogen peroksida sebanyak $0,75 \mathrm{~mol} / \mathrm{mol}$ unit isoprena.

Analisis gugus fungsi berdasarkan spektrum FTIR karet terepoksidasi menunjukkan pita karakteristik untuk cincin epoksida pada bilangan gelombang $870 \mathrm{~cm}^{-1}$ semakin tinggi intensitasnya sementara puncak olefin yang tidak termodifikasi pada bilangan gelombang $835 \mathrm{~cm}^{-1}$ semakin menurun intensitasnya dibandingkan dengan spektrum FTIR karet alam (Gambar 2). Hal ini menunjukkan bahwa lateks DPNR telah berhasil diepoksidasi.

Hasil pengukuran spektrum FTIR untuk lateks terepoksida pada berbagai variasi suhu, waktu, dan kecepatan pengadukan dapat dilihat pada Tabel 2. Dari tabel tersebut dapat dilihat bahwa semakin lama waktu reaksi intensitas dari puncak pada bilangan gelombang $870 \mathrm{~cm}^{-1}$ semakin meningkat sementara intensitas dari puncak pada bilangan gelombang $835 \mathrm{~cm}^{-1}$ semakin menurun. Hal tersebut menunjukkan bahwa selama reaksi telah terjadi oksidasi ikatan rangkap $\mathrm{C}=\mathrm{C}$ dari unit isoprena karet alam membentuk ikatan $\mathrm{C}-\mathrm{O}$ dari gugus oksiran. Semakin tinggi intensitas dari puncak pada bilangan gelombang $870 \mathrm{~cm}^{-1}$ menunjukkan semakin banyak gugus oksiran yang terbentuk yang berarti semakin besar mol epoksi yang dihasilkan.

Tabel 2. Persen mol epoksi (E) dan cincin terbuka (R) pada variasi suhu, waktu, dan kecepatan pengadukan.

\begin{tabular}{|c|c|c|c|c|c|c|c|}
\hline \multirow{3}{*}{ Suhu $\left({ }^{\circ} \mathrm{C}\right)$} & \multirow{3}{*}{$\begin{array}{l}\text { Waktu } \\
\text { (jam) }\end{array}$} & \multicolumn{6}{|c|}{ Kecepatan pengadukan (rpm) } \\
\hline & & \multicolumn{2}{|c|}{125} & \multicolumn{2}{|c|}{350} & \multicolumn{2}{|c|}{700} \\
\hline & & $\mathrm{E}(\%)$ & $\mathrm{R}(\%)$ & $\mathrm{E}(\%)$ & $\mathrm{R}(\%)$ & $\mathrm{E}(\%)$ & $\mathrm{R}(\%)$ \\
\hline \multirow{4}{*}{60} & 1 & 5,69 & 1,07 & 5,05 & 1,91 & 4,35 & 1,54 \\
\hline & 2 & 10,76 & 1,36 & 10,11 & 3,14 & 11,27 & 0,76 \\
\hline & 3 & 15,03 & 2,82 & 15,80 & 0,81 & 16,29 & 1,08 \\
\hline & 4 & 20,40 & 1,38 & 20,68 & 1,15 & 21,56 & 2,02 \\
\hline \multirow{4}{*}{70} & 1 & 14,61 & 0,57 & 11,57 & 1,05 & 14,80 & 0,25 \\
\hline & 2 & 21,78 & 0,85 & 20,09 & 0,53 & 24,51 & 0,27 \\
\hline & 3 & 29,26 & 0,30 & 27,22 & 1,40 & 32,37 & 0,93 \\
\hline & 4 & 32,95 & 1,16 & 33,10 & 2,26 & 37,76 & 1,75 \\
\hline \multirow{4}{*}{80} & 1 & 23,25 & 1,13 & 26,66 & 0,24 & 21,04 & 1,81 \\
\hline & 2 & 32,65 & 1,04 & 36,05 & 0,81 & 32,19 & 1,79 \\
\hline & 3 & 38,96 & 3,32 & \multicolumn{4}{|c|}{ Lateks menggumpal } \\
\hline & 4 & \multicolumn{6}{|c|}{ Lateks menggumpal } \\
\hline
\end{tabular}


Tabel 2 memperlihatkan pengaruh suhu, waktu, dan kecepatan pengadukan terhadap reaksi epoksidasi. Semakin tinggi suhu, persen mol epoksi yang dihasilkan semakin besar, akan tetapi suhu di atas $70^{\circ} \mathrm{C}$ sangat mengganggu kestabilan lateks, reaksi lebih dari 3 jam menyebabkan lateks menggumpal. Oleh karena itu suhu optimum dipilih pada $70^{\circ} \mathrm{C}$. Semakin lama waktu reaksi, persen mol epoksi yang dihasilkan semakin besar. Kenaikan kecepatan pengadukan tidak terlalu berpengaruh terhadap persen mol epoksi yang dihasilkan. Namun kecepatan pengadukan yang tinggi dapat memperkecil terjadinya transfer massa sehingga kecepatan optimum dipilih pada $700 \mathrm{rpm}$.

\section{Pengikatan Antioksidan Melalui Gugus Epok- si}

Lateks hasil epoksidasi masih mengandung asam format dan hidrogen peroksida sisa yang tidak bereaksi. Kedua bahan tersebut harus dinetralkan terlebih dahulu sebelum lateks epoksi direaksikan dengan antioksidan untuk menghindari terjadinya reaksi samping. Asam format dinetralkan dengan amonia sampai $\mathrm{pH} 7$ untuk mencegah terjadinya konversi gugus amina dari antioksidan menjadi garam amonium kuartener dalam medium asam. Garam amonium kuartener dapat bereaksi dengan gugus oksiran menghasilkan senyawa yang tidak diinginkan yaitu tetrahidrofuranil (Wibowo et al., 2014). Sementara itu hidrogen peroksida harus dinetralkan untuk mencegah terjadinya oksidasi lateks oleh gugus peroksida.

Analisis gugus fungsi berdasarkan spektrum FTIR untuk lateks mengikat antioksidan menunjukkan puncak pada bilangan gelombang 1596

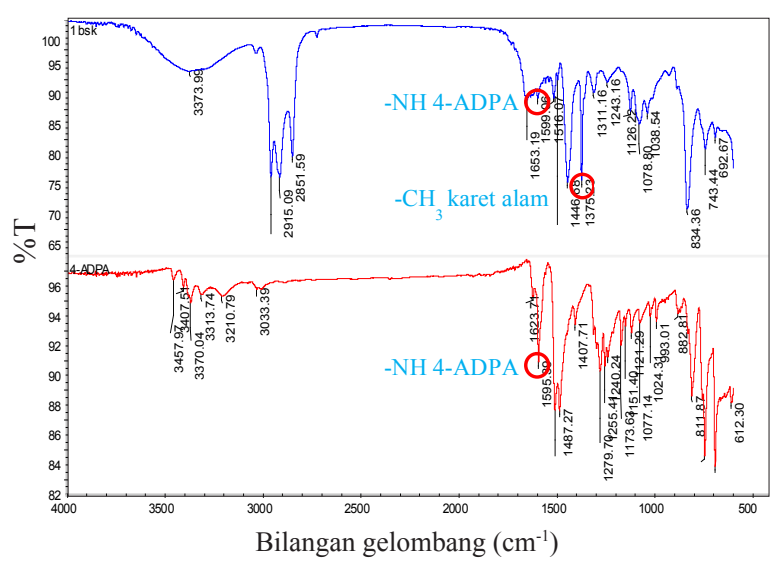

Gambar 3. Perbandingan spektrum FTIR karet mengikat antioksidan 4-ADPA sebanyak $1 \mathrm{phr}$ (biru) dengan senyawa 4-ADPA (merah). $\mathrm{cm}^{-1}$ dan $1375 \mathrm{~cm}^{-1}$ yang karakteristik untuk gugus -NH dari 4-ADPA dan gugus $-\mathrm{CH}_{3}$ dari karet alam (Gambar 3). Hal ini menunjukkan bahwa karet telah mengikat antioksidan.

Dari Gambar 3 dapat dilihat bahwa pada spektrum yang berwarna biru (karet mengikat 4-ADPA) muncul puncak baru pada bilangan gelombang $1599 \mathrm{~cm}^{-1}$ yang karakteristik untuk serapan dari gugus -NH 4-ADPA serta adanya serapan pada bilangan gelombang $1375 \mathrm{~cm}^{-1}$ yang karakteristik untuk gugus $-\mathrm{CH}_{3}$ dari karet alam. Hal tersebut menunjukkan terjadinya reaksi pengikatan 4-ADPA ke dalam karet alam. Akan tetapi intensitas pada bilangan gelombang $1599 \mathrm{~cm}^{-1}$ dari karet yang sudah mengikat 4-ADPA lebih rendah dibandingkan dengan puncak dari senyawa 4-ADPA pada bilangan gelombang yang sama. Hal ini disebabkan jumlah 4-ADPA yang terikat relatif sedikit (hanya $1 \mathrm{phr}$ ). Semakin banyak jumlah antioksidan yang terikat, intensitasnya akan semakin tinggi.

Data pada Tabel 3 memperlihatkan bahwa penambahan dosis 4-ADPA di bawah $0,1 \mathrm{~mol} / 100$ gram karet belum menghasilkan karet yang terikat antioksidan. Sementara itu penambahan 4-ADPA juga telah dilakukan pada suhu $40^{\circ} \mathrm{C}$ untuk melihat pengaruhnya jika dilakukan pada suhu di bawah $60^{\circ} \mathrm{C}$ akan tetapi hasilnya sama, lateks menggumpal kurang dari dua jam. Dengan demikian dapat disimpulkan bahwa reaksi penambahan 4-ADPA pada suhu di atas suhu $27^{\circ} \mathrm{C}$ menyebabkan kestabilan lateks terganggu sehingga lateks menggumpal dalam waktu kurang dari 2 jam meskipun telah dilakukan penambahan surfaktan emulgen sebanyak 5 phr untuk mempertahankan kestabilan lateks. Hal ini dapat disebabkan karena penambahan natrium tiosulfat pada saat penetralan dan antioksidan 4-ADPA menyebabkan penurunan cloud point dari surfaktan sehingga kemampuannya untuk menstabilkan lateks menurun. Reaksi pengikatan antioksidan dapat terjadi pada suhu kamar setelah reaksi selama 24 jam. Pengikatan optimum diperoleh pada lateks epoksi yang direaksikan selama 3 jam yaitu sebesar 1,93 phr.

Secara visual, terjadi perbedaan warna dan bentuk antara karet krep sebelum reaksi pengikatan dan sesudah reaksi pengikatan seperti terlihat pada Gambar 4. Dari gambar tersebut dapat dilihat bahwa karet (b) lebih rapuh dibandingkan dengan karet (a). Hal ini dapat disebabkan karena pada karet (b) telah terikat antioksidan di dalamnya se- 
Tabel 3. Hasil penambahan antioksidan 4-ADPA pada variasi lateks epoksi dengan suhu epoksidasi $70^{\circ} \mathrm{C}$ dan kecepatan pengadukan $700 \mathrm{rpm}$.

\begin{tabular}{cccccc}
\hline \multirow{2}{*}{ Waktu epoksidasi $\begin{array}{c}\text { Dosis antioksidan } \\
(\text { mol/100 gram karet) }\end{array}$} & \multicolumn{4}{c}{ Jumlah 4-ADPA terikat (phr) } \\
\cline { 3 - 6 } & & $\left.27^{*}\right)$ & 60 & 70 & 80 \\
\cline { 3 - 6 } 1 & 0,025 & 0 & NA & NA & NA \\
& 0,05 & 0 & NA & NA & NA \\
& 0,1 & 0,6 & NA & NA & NA \\
\hline \multirow{2}{*}{2} & 0,025 & 0 & NA & NA & NA \\
& 0,05 & 0 & NA & NA & NA \\
& 0,1 & 1,63 & NA & NA & NA \\
\hline \multirow{2}{*}{3} & 0,025 & 0 & NA & NA & NA \\
& 0,05 & 0 & NA & NA & NA \\
& 0,1 & 1,93 & NA & NA & NA \\
\hline \multirow{2}{*}{4} & 0,025 & 0 & NA & NA & NA \\
& 0,05 & 0 & NA & NA & NA \\
& 0,1 & 1,49 & NA & NA & NA \\
\hline
\end{tabular}

\section{Keterangan:}

$\mathrm{NA}=$ Tidak dapat dihitung karena lateks menggumpal kurang dari 2 jam

${ }^{*}$ Pengujian dilakukan setelah reaksi dibiarkan selama 24 jam

hingga mempengaruhi struktur molekul karet alam. Adanya gugus meruah dari 4-ADPA yang terikat pada karet alam menyebabkan keteraturan rantai dari polimer karet alam menjadi berkurang sehingga strukturnya menjadi lebih amorf dan jarak antar rantainya menjadi lebih renggang akibatnya karet menjadi lebih rapuh dan lebih mudah sobek ketika digiling di dalam gilingan kreper. Dalam hal warna, karet (b) warnanya menjadi hitam yang berasal dari warna 4-ADPA yang ditambahkan ke dalam lateks.

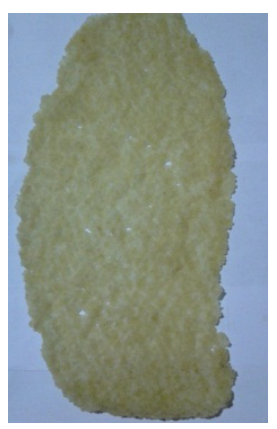

(a)

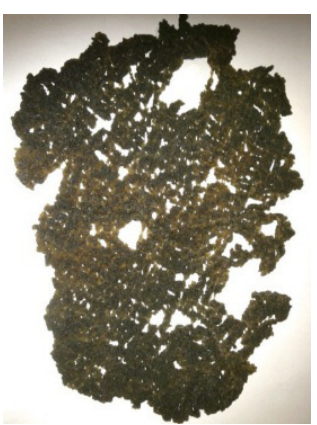

(b)
Gambar 4. Gambar karet krep: (a) sebelum reaksi pengikatan dan (b) sesudah reaksi pengikatan.

\section{Penentuan Jumlah Antioksidan Terikat}

Jumlah antioksidan yang terikat diperoleh dengan cara mengekstrapolasikan hasil perbandingan absorbansi pada bilangan gelombang 1596 $\mathrm{cm}^{-1}$ dan $1375 \mathrm{~cm}^{-1}$ ke dalam kurva standar. Gambar 5 menunjukkan kurva standar yang diperoleh dari pencampuran secara fisika karet alam dengan antioksidan pada dosis 1, 2, 3, 4, dan 5 phr (Barra et al., 1999). Dari kurva standar diperoleh persamaan regresi linearnya yang kemudian digunakan untuk menghitung jumlah 4-ADPA terikat.

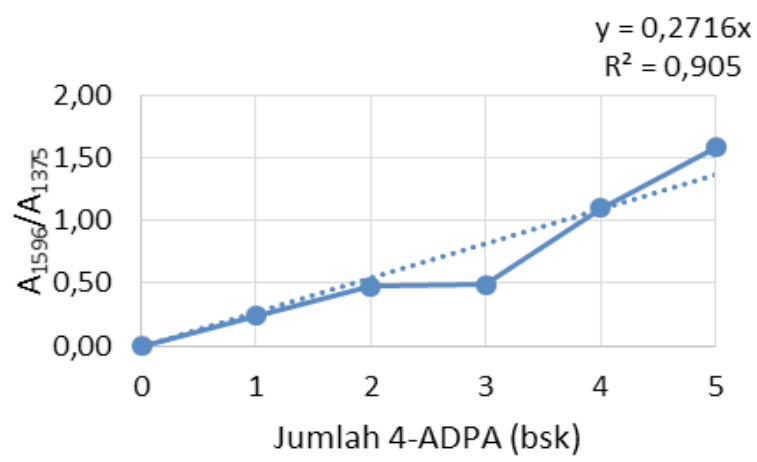

Gambar 5. Kurva standar pencampuran secara fisika karet alam dengan 4-ADPA sebanyak 1-5 phr. 
Tabel 4. Data reometer vulkanisat A, B, C, dan D.

\begin{tabular}{cccccc}
\hline Vulkanisat & $\begin{array}{c}\mathrm{S}_{\max } \\
(\mathrm{kg}-\mathrm{cm})\end{array}$ & $\begin{array}{c}\mathrm{S}_{\text {Min }} \\
(\mathrm{kg}-\mathrm{cm})\end{array}$ & $\begin{array}{c}\mathrm{S}_{\max }-\mathrm{S}_{\text {Min }} \\
(\mathrm{kg}-\mathrm{cm})\end{array}$ & $\begin{array}{c}\mathrm{T}_{90} \\
\text { (menit:detik) }\end{array}$ & $\begin{array}{c}\text { Scorch time } \\
\text { (menit:detik) }\end{array}$ \\
\hline $\mathrm{A}$ & 2,15 & 0,17 & 1,98 & 10,21 & - \\
$\mathrm{B}$ & 2,52 & 0,24 & 2,28 & 9,48 & 9,12 \\
$\mathrm{C}$ & 4,03 & 0,42 & 3,61 & 7,54 & 3,52 \\
$\mathrm{D}$ & 1,58 & 0,24 & 1,34 & 12,12 & - \\
\hline
\end{tabular}

Tabel 5. Persen reversi kompon karet.

\begin{tabular}{ccccc}
\hline Vulkanisat & $\mathrm{S}_{\max }$ & $\mathrm{S}_{300 \mathrm{~s}}$ & $\mathrm{~S}_{\max }-\mathrm{S}_{300 \mathrm{~s}}$ & $\mathrm{R}_{300}(\%)$ \\
\hline $\mathrm{A}$ & 2,15 & 2,05 & 0,1 & 4,65 \\
$\mathrm{~B}$ & 2,52 & 2,4 & 0,12 & 4,76 \\
$\mathrm{C}$ & 4,03 & 3,85 & 0,18 & 4,47 \\
$\mathrm{D}$ & 1,58 & 1,56 & 0,02 & 1,27 \\
\hline
\end{tabular}

Penentuan Ketahanan Usang berdasarkan Kurva Reometer

Hasil optimum dari reaksi pada skala kecil selanjutnya dibuat pada skala besar (reaktor 2 L) untuk pembuatan vulkanisat. Hasil pada skala yang lebih besar menunjukkan jumlah 4-ADPA yang terikat menurun menjadi 1,47 phr pada kondisi suhu dan pengadukan yang sama dengan skala kecil. Hal ini disebabkan terjadi perbedaan kondisi antara skala kecil dengan skala besar diantaranya perbedaan transfer panas antara reaktor kecil dengan reaktor besar sehingga akan memberikan pengaruh yang berbeda. Untuk reaksi pada suhu yang sama, reaktor yang besar memberikan hasil yang lebih rendah dibandingkan dengan reaktor yang kecil.

Ketahanan usang dari vulkanisat karet dapat ditentukan berdasarkan kurva reometer yang diperoleh. Data kurva reometer untuk keempat vulkanisat yang dibuat dapat dilihat pada Tabel 4. Dari data reometer dapat ditentukan nilai $\mathrm{R}_{300}$. Harga $\mathrm{R}_{300}$ adalah persen reversi untuk kompon yang menunjukkan ketahanan kompon terhadap pengusangan (Khang \& Ariff, 2011). Semakin kecil nilai $\mathrm{R}_{300}$ berarti kompon tersebut semakin tahan terhadap pengusangan.

Persen reversi untuk keempat kompon setelah dihitung dapat dilihat pada Tabel 5. Dari tabel

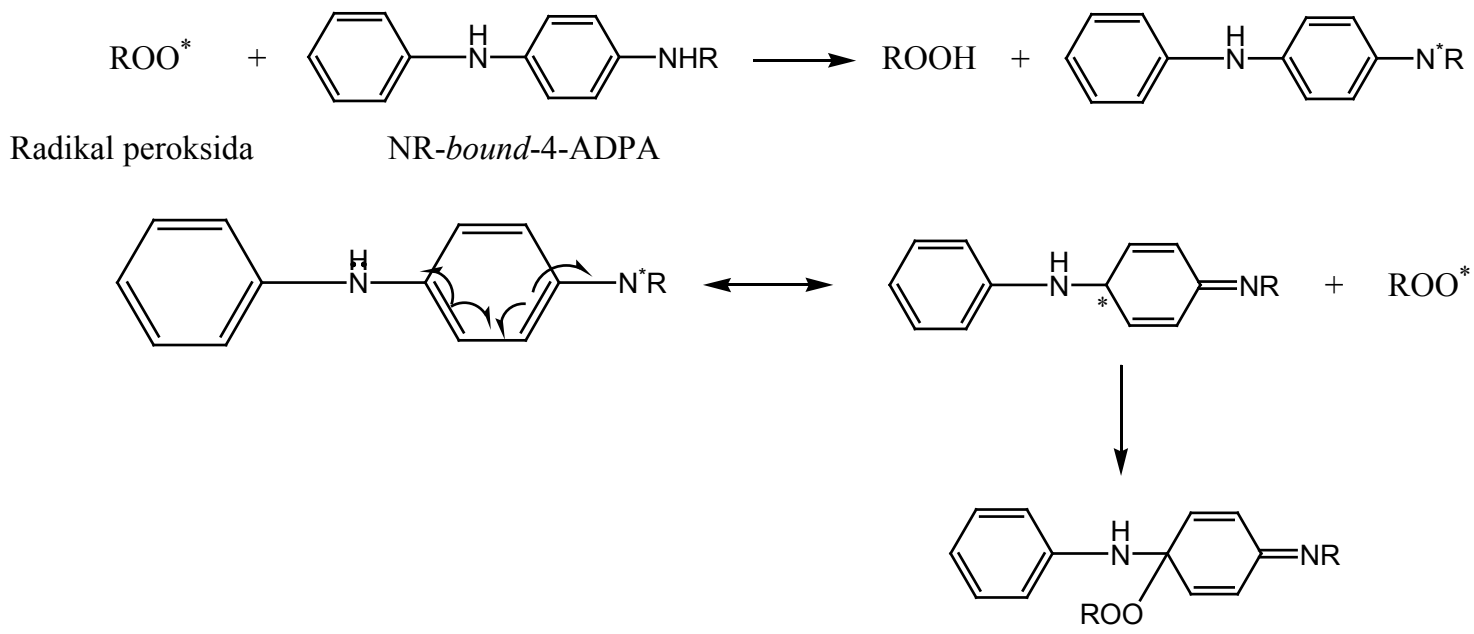

Produk non radikal

Gambar 6. Mekanisme NR-bound-4-ADPA mencegah oksidasi karet alam pada tahap propagasi rantai $(\mathrm{R}=$ karet alam $)$. 
tersebut diketahui nilai $\mathrm{R}_{300}$ paling rendah untuk kompon $\mathrm{D}$ yaitu kompon yang menggunakan karet mengikat antioksidan secara kimia.

Berdasarkan nilai tersebut dapat disimpulkan bahwa kompon D paling tahan terhadap pengusangan dibandingkan kompon yang lain. Sedangkan untuk kompon B dimana antioksidan terikat secara fisik, ketahanan reversinya lebih rendah dibandingkan dengan kompon D. Hal ini dapat disebabkan karena antioksidan yang terikat secara fisika mudah mengalami migrasi ke permukaan sehingga daya antioksidasinya menurun karena hilangnya bahan antioksidan selama komponding.

Antioksidan yang terikat secara kimia ikatannya lebih kuat sehingga pada saat komponding tidak terjadi migrasi antioksidan ke permukaan. Antioksidan yang terikat secara kimia pada karet dapat bekerja secara maksimal mencegah oksidasi pada karet alam dengan cara mempengaruhi pada tahap propagasi rantai. Kemungkinan mekanisme inhibisinya dapat dilihat pada Gambar 6 .

Dari Gambar 6 dapat dilihat bahwa dengan adanya antioksidan yang terikat secara kimia pada karet alam menyebabkan terjadinya halangan sterik sehingga kemampuan radikal peroksida untuk mengabstraksi atom $\mathrm{H}$ dari karet alam menurun. Akibatnya radikal peroksida akan mengabstraksi atom $\mathrm{H}$ dari gugus amina pada senyawa 4-ADPA membentuk senyawa peroksida dan radikal baru yang bisa mengalami delokalisasi elektron menghasilkan radikal yang lebih stabil. Radikal tersebut kemudian bereaksi dengan radikal peroksida yang lain membentuk produk non radikal yang cukup stabil. Dengan demikian reaksi oksidasi karet alam dapat dicegah.

\section{KESIMPULAN}

Berdasarkan hasil penelitian yang dilakukan, dapat disimpulkan bahwa hasil reaksi epoksidasi menunjukkan bahwa suhu dan lama waktu reaksi berpengaruh terhadap persen mol epoksi yang dihasilkan. Semakin tinggi suhu dan semakin lama waktu reaksi persen mol epoksi yang dihasilkan semakin besar. Kecepatan pengadukan tidak terlalu berpengaruh terhadap persen mol epoksi, namun kecepatan pengadukan yang tinggi dapat memperkecil terjadinya transfer massa sehingga kecepatan optimum dipilih pada $700 \mathrm{rpm}$.

Pengikatan 4-ADPA dapat terjadi pada dosis minimal $0,1 \mathrm{~mol} / 100$ gram karet dengan suhu optimum untuk pengikatan adalah pada $27^{\circ} \mathrm{C}$. Penggunaan suhu di atas suhu tersebut sangat meng- ganggu kestabilan lateks. Hasil pengukuran spektrum FTIR menunjukkan telah terjadi pengikatan 4-ADPA ke dalam lateks yang telah terepoksidasi sebanyak 1,93 phr sedangkan hasil analisis kurva reometer menunjukkan karet yang terikat 4-ADPA secara kimia lebih tahan terhadap pengusangan berdasarkan nilai $\mathrm{R}_{300}$.

\section{UCAPAN TERIMA KASIH}

Ucapan terima kasih penulis sampaikan kepada Direktur Pusat Penelitian Karet atas bantuan dananya untuk penelitian ini.

\section{DAFTAR PUSTAKA}

Barra, G. M., Crespo, J. S., Bertolino, J. R., Soldi, V., \& Pires, A. T. N. (1999). Maleic anhydride grafting on EPDM: Qualitative and quantitative determination. Journal of the Brazilian Chemical Society, 10(1), 31-34, http://dx.doi.org/10.1590/ S0103-50531999000100006

Chakraborty, S., Kar, S., Ameta, R., Dasgupta, S., \& Mukhopadhyay, R. (2010). Quantitative application of FTIR in rubber. Rubber World: The Technical Service Magazine for The Rubber Industry, 241(4): 33-39.

Deptan. (2016). Basis Data Statistik Pertanian. https://aplikasi.pertanian.go.id/bdsp/, diakses 26 September 2016.

Faturrahman, M. I., Handayani, H., \& Kuncoro, I. (2011). Pengembangan modifikasi karet alam tahan minyak/pelumas (Laporan akhir Kerjasama Penelitian). Pusat Penelitian Karet, Indonesia.

Khang, T. H., \& Ariff, Z. M. (2011). Vulcanization kinetics study of natural rubber compounds having different formulation variables. Journal of Thermal Analysis and Calorimetry, 109(3), 15451553 , http://dx.doi.org/10.1007/s10973-011-1937-3

Klinpituksa, P., Hamad, A., Nakason, C., \& Kaesaman, A. (2011). Natural rubber bound4-aminodiphenylamine antioxidant for rubber formulation improvement. Science Journal Ubon Ratchathani University, 2(1), 66-71.

Phinyocheep, P., Phetphaisit, C. W., Derouet, D., Campistron, I., \& Brosse, J. C. (2005). Chemical degradation of epoxidized natural rubber using periodic acid: Preparation of epoxidized liquid natural rubber. Journal of applied polymer science, 95(1), 6-15, http://dx.doi.org/10.1002/app.20812

Phinyocheep, P., \& Boonjairaak, K. (2006). Investigation on hydrogenation and epoxidation of natural rubber in latex stage. Department of Chemistry, Faculty of Science, Mahidol University, Bangkok.

Phinyocheep, P. (2014). Chemical modification of 
natural rubber for improved performance. In S. Kohjiya \& Y. Ikeda (Eds.). Chemistry, manufacture and applications of natural rubber (pp. 68110). Cambridge, United Kingdom: Woodhead Publishing.
Wibowo, T. Y., Rusmandana, B., \& Astuti, A. (2014). Degradasi cincin oksiran dari epoksi asam oleat dalam suatu sistem reaksi katalis cair. Jurnal Teknologi Pertanian, 14(1), 29-34. 